\title{
Helsevesen eller romvesen?
}

\section{Jeg har vært bortført av romvesener.}

Eller - jeg har vært pasient, som

dere også kaller det. Jeg fikk dia-

gnosen brystkreft for rundt tre år

siden og ble bortført til det ytre rom

ganske så umiddelbart. De tok meg

til en planet de kalte Helsevesenet.

$\AA$ A havne i helsevesenet som pasient med en alvorlig diagnose er virkelig som å havne på en annen planet. Her har du gått rundt i alle år og sett på deg selv som et voksent, reflektert og oppegående menneske folk bør snakke til med et minimum av respekt, men den gang ei.

Etter noen konsultasjoner der hvite frakker snakker til deg enten i så tekniske vendinger at du begynner å angre på at du ikke tok doktorgraden i medisin da du hadde sjansen eller pludrer til deg på omsorgsfullt babyspråk, har du bare lyst til å skrike: «Take me to your leader!»

Særlig med tanke på alle undersøkelsene vi skal igjennom. Hele fire ganger er jeg blitt stappet inn i et sånt MR-rør. Det ser jo helt ut som noe man bare finner i sånne kvasidokumentarer om folk som mener de er blitt bortført av romvesener på ordentlig. Dere har stukket meg med tykke nåler for å ta vevsprøver, operert meg, drenert meg for sårvæske, pumpet meg full av cellegift, skannet og bestrålt meg.

Alt i alt føler jeg virkelig at jeg har mitt på det tørre når jeg sier at jeg har vært bortført av romvesener. Men etter hvert ser jo i hvert fall vi kreftpasienter ut som romvesener selv også. Håret detter av og fasongen blir som formen på en middels brunsnegle. Det er også nå vi begynner å få sympati for romvesenene som har bortført oss, et slags stockholmssyndrom setter inn. Vi pasienter begynner etter hvert å snakke som dere romvesener $i$ helsevesenet. Vi slenger rundt oss med begreper som epikrise og resistens uten å blunke.

Vi begynner å forstå dere. Skjønne hvorfor vi bare er brikker i et puslespill. Forstå at vi bare er enda en jobb, enda et nummer i rekken. For hvem orker vel å møte så mange individer menneske til menneske? Hvem klarer vel å se det spesielle i det generelle når kreftbehandling og tilbakefall er hverdagskost?

Men det er altså ikke hverdagskost for oss. For oss er det krise. For oss er det unntakstilstand. For oss er selve helvete løs samtidig som vi prøver å ta eksamen i medisin via Google.

Dagens pasienter kommer nemlig til helsevesenet ferdig uteksaminert fra Google. Men vi er helt uten verktøy til å hanskes med kunnskapen vi har fått. Google blir vår avgud. Vårt eneste korrektiv. Alteret vi ber ved. Simultantolken vi oppsøker for å få oversatt romvesenpratet deres. Google blir vår «precious». «My precious», stønner vi og googler i vei som den litt mer matglade kusinen til Gollum i Ringenes herre.

Det er likevel ikke før mot slutten av kreftbehandlingen at dere romvesener i helsevesenet føler at dere har oss til- strekkelig under kontroll med fullt stockholmssyndrom til at dere tør vise oss selve romskipet. Glem alt jeg har sagt om MRmaskinen. Det er strålemaskinen som er alle romvesenmaskiners mor!

Den er et sinnssykt, utenomjordisk opplegg - som involverer et par RoboCop-briller med dataskjerm inni, noen fargestriper og en maskin som over høyttalere kommanderer deg til å puste inn og ut. Etter dager og uker inn og ut av den strålemaskinen får vi en siste samtale med kapteinen på romskipet, som går under navnet onkolog. Så teleporteres vi tilbake til vår egen planet.

Som Mr. Bean står vi plutselig på gaten og skjønner ikke en dritt. Legene glemte nemlig helt å fortelle om den fyllefesten av senskader og bivirkninger vi nå kan glede oss til. Vi skal jo bare være glad til for at vi har overlevd.

Norsk helsevesen er blitt en av verdens beste maskiner, men det er fortsatt en maskin. Den menneskelige faktoren begrenser seg altfor ofte til brosjyrer i sirlige bunker på venterommet. Som det arket jeg fant mens jeg ventet på stråleterapi en dag: «Vi trenger dine innspill for å bli bedre!» Vel, la dette være mitt innspill til dere i helsevesenet, men kanskje særlig til dem som bestemmer: Selv verdens beste maskiner må bygges og driftes av mennesker, ikke av romvesener, for å fungere.

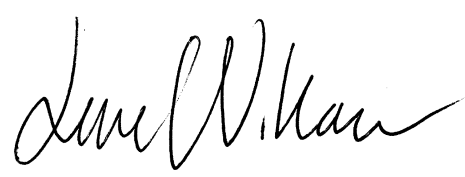

